\title{
IMPACT OF SPOILAGE MICROORGANISMS ON SOME DAIRY PRODUCTS
}

\author{
GAMAL M. HASSAN, ARAFA M.S. MESHREF, MOHAMED M.A. ZEINHOM \\ and MOHAMED S. ABDEL-HALEM \\ Food Hygiene and Control Department, Faculty of Veterinary Medicine, Beni-Suef University, \\ Beni-Suef 62512, Egypt.
}

Received: 4 March 2019; $\quad$ Accepted: 31 March 2019

\begin{abstract}
Food spoilage is a complex process and excessive amounts of foods are lost due to microbial spoilage even with modern day preservation techniques. The aim of this study was to assess the microbiological quality of some dairy products in Beni-suef city, Egypt. A total of 210 samples of some dairy products (Kareish, Tallaga, Ras cheeses, small scale and large scale yoghurt, small scale and large scale cream samples) (30 of each) were collected from local retail stores, dairy shops and farmers' markets in Beni-Suef city. All samples were analysed for total bacterial count (TBC), total coliforms count, total yeast and mold count, total psychrotrophic count, lipolytic count and proteolytic count. The mean value of Kareish cheese and small scale cream for TBC were $1.07 \times 10^{7} \pm 5.64 \times 10^{6}$ and $3.35 \times 10^{6} \pm 1.23 \times 10^{6} \mathrm{cfu} / \mathrm{g}$, respectively. The mean values of Kareish, Tallaga, Ras cheeses, small scale yoghurt and small scale cream for total coliforms count were $2.55 \times 10^{5} \pm 1.59 \times 10^{5}, 9.58 \times 10^{2}$ $\pm 4.32 \times 10^{2}, 88.10 \pm 21.11,1.94 \times 10^{2} \pm 79.47$ and $1.58 \times 10^{4} \pm 5.85 \times 10^{3} c f u / g$, respectively. The mean values for total yeast and mold count were $1.83 \times 10^{5} \pm 9.25 \times 10^{4}, 6.10 \times 10^{2} \pm 3.35 \times 10^{2}, 54.67 \pm 22.04,2.66 \times 10^{5} \pm 8.07 \times 10^{4}$ and $2.57 \times 10^{4} \pm 2.10 \times 10^{4} \mathrm{cfu} / \mathrm{g}$, respectively. The mean values for total psychrotrophic count were $2.89 \times 10^{7} \pm$ $1.36 \times 10^{7}, 1.16 \times 10^{6} \pm 7.00 \times 10^{5}, 2.46 \times 10^{6} \pm 4.50 \times 10^{5}, 7.81 \times 10^{5} \pm 3.37 \times 10^{5}$ and $2.51 \times 10^{6} \pm 6.95 \times 10^{5} \mathrm{cfu} / \mathrm{g}$, respectively. The mean values for lipolytic count were $1.23 \times 10^{6} \pm 5.18 \times 10^{5}, 9.32 \times 10^{5} \pm 5.63 \times 10^{5}, 2.91 \times 10^{6} \pm$ $4.13 \times 10^{5}, 2.32 \times 10^{5} \pm 8.68 \times 10^{4}$ and $3.00 \times 10^{6} \pm 7.34 \times 10^{5} \mathrm{cfu} / \mathrm{g}$, respectively. The mean value for proteolytic count were $1.16 \times 10^{6} \pm 4.88 \times 10^{5}, 9.94 \times 10^{5} \pm 6.03 \times 10^{5}, 5.85 \times 10^{6} \pm 7.58 \times 10^{5}, 3.32 \times 10^{5} \pm 2.12 \times 10^{5}$ and $5.21 \times 10^{6}$ $\pm 1.27 \times 10^{6} \mathrm{cfu} / \mathrm{g}$, respectively. In conclusion, the presence of these organisms indicated that the examined dairy products were of inferior quality which reflects unhygienic measures, inadequate heat treatment during the manufacture, using bad quality ingredients or additives and improper sanitation during handling, storage and distribution.
\end{abstract}

Key words: Lipolytic bacteria, Spoilage, Coliforms, Ras cheese, Yoghurt

\section{INTRODUCTION}

Milk and dairy products such as cheese are rich in nutrients such as protein, calcium, vitamins, phosphorus, magnesium, zinc, etc. providing a major part of human food, due to high nutritive value of these products, they provide a good media for the growth and multiplication of many of microorganisms (Ledenbach and Marshall, 2009; Pal and Awel, 2014).

Cheese is essentially a microbial fermentation of milk by selected lactic acid bacteria whose major function is to produce lactic acid from lactose causing curd formation, the poor hygienic conditions during milking and cheese making and the inappropriate

Corresponding author: Dr. MOHAMED S. ABDEL- HALEM

E-mail address: msafwat1992@yahoo.com

Present address: Food Hygiene and Control Department, Faculty of Veterinary Medicine, Beni-Suef University, Beni-Suef 62512, Egypt. conditions of their storage negatively influenced the cheese quality (Özdemir et al., 2010). Kareish cheese is the most popular local types of soft cheese in Egypt, characterized by low fat content, sources of protein, calcium, phosphorus and water soluble vitamins, (El-Bagoury and Mosaad, 2002).

Yoghurt is one of the most popular fermented dairy products which have a wide acceptance worldwide that obtained by controlled fermentation of milk by lactic acid bacteria, which is carried out specifically by Lactobacillus bulgaricus and Streptococcus thermophiles (Tamime and Robisons, 2007). It is considered a nutrient dense food, whereas it's highly nutritious, easily digestible and a source of more than ten essential nutrients, certain minerals and vitamins (Weerathilake et al., 2014). The changes in the physical, chemical and microbiological structures of yoghurt determine the storage and shelf life of the product (Sofu and Ekinci, 2007).

Cream is effectively a selective milk concentrate containing an elevated level of milk fat globules 
dispersed in a continuous phase of skim milk; it provides both a valued range of products and the raw material for butter production. Common taints found in cream include sour, rancid, cheesy, stale, bitter, putrid, and yeasty; a slight, ill-defined taint may be described as stale or unclean. Ropiness or sliminess may be caused by some coliforms or lactococci (Wilbey, 2005).

Spoilage microorganisms cause changes of primary characteristics and properties of milk and dairy products. The product defects depend on the specific species and number of microorganisms involved in pre- and post- technological processing. Most often, these changes are related to single undesirable sensory characteristic, smell, flavour or consistency (Samaržija et al., 2007).

Total counts of bacteria are the most useful indication of microbiological status of dairy products. High levels indicate raw material contamination, improper sanitation or unsuitable time and temperature factors during storage and production (Mossel, 1983).

Coliforms, defined as aerobic or facultative anaerobic, Gram-negative, non-spore-forming rods capable of fermenting lactose with the production of acid and gas at $32-35^{\circ} \mathrm{C}$ (Davidson et al., 2004). The presence of coliforms has long been thought to indicate faecal contamination, however, recent discoveries regarding this diverse group of bacteria indicates that only a fraction are faecal in origin, while the majority are environmental contaminants. Coliforms are common contaminants in cheeses and other dairy products (Wolfe et al., 2014).

Yeasts are the most important contaminants in some types of dairy products. This is especially relevant in fermented products such as yoghurt and sour milk, where yeast species are the major cause of spoilage because the low $\mathrm{pH}$ provides a suitable environment for their growth (Rohm et al., 1992). Molds have pathogenic, allergic and toxic effect also their presence in high levels in dairy products may cause a risk to human health especially immunocompromised (Minervini et al., 2001).

The term psychrotrophs (also denominated psychrotolerant) refers to microorganisms able to grow at low temperatures and have optimal and maximal growth temperatures above 15 and $20{ }^{\circ} \mathrm{C}$, respectively (Moyer and Morita, 2007). Moreover psychrotophic bacteria have the ability to produce heat stable extracellular and/ or intracellular hydrolytic enzymes (Chen et al., 2003) and enter processed dairy products through post- pasteurization contaminants in the milk processing plant (Ralyea et al., 1998).

Lipolytic microorganisms are known to induce certain objectionable changes in the butter fat of dairy products rendering them unmarketable or unfit for human consumption. Most of them play a role in maturation of cheese or in inducing a desirable flavour (Death and Fitz-Gerald, 1983).

Proteolytic microorganisms degrade protein and cause bitterness and putrefaction to some dairy products. The proteolytic enzymes produced by psychrotrophs in milk are more powerful in its action on milk protein than that naturally present in milk and that produced by leucocytes even if present by great amount (Grieve and Kitchen, 1985). Therefore, this study was conducted to evaluate the microbiological quality of some dairy products (Cheese, Yoghurt and cream) and discuss the economic and public health hazards of these microorganisms.

\section{MATERIALS AND METHODS}

\section{1- Collection of samples:}

A total of 210 samples of dairy products consisting of Kareish, Tallaga, Ras cheeses, fresh cream, large scale cream, small-scale yoghurt and large scale yoghurt (30 of each) were collected from local retail stores, dairy shops and farmers' markets in Beni-Suef city, Egypt.

\section{2- Preparation of dairy samples: (APHA, 1992)}

Ten $\mathrm{g}$ of cheese samples was homogenized with 90 $\mathrm{ml}$ of $2 \%$ sterilized sodium citrate solution in sterile blender for $2 \mathrm{~min}$. Ten $\mathrm{g}$ of cream and yoghurt samples were mixed with $90 \mathrm{ml}$ of sterile saline or distilled water. Additional 10-fold serial dilutionswere prepared with the same diluent and appropriate dilutions were used to enumerate the different groups of microorganisms.

\section{3- Microbiological examination:}

\subsection{Total Aerobic plate count: (APHA, 1992)}

One $\mathrm{ml}$ of each dilution was transferred into duplicated labelled petri dishes. 12 to $15 \mathrm{ml}$ of liquefied sterile plate count agar (PCA) at $44^{\circ} \mathrm{C}-46^{\circ} \mathrm{C}$ were poured into each plate, then incubation at $35^{\circ} \mathrm{C}$ for 48 hours.

\subsection{Total coliforms count using Most Probable} Number (MPN) technique: (FAO, 1992)

One $\mathrm{ml}$ from previously prepared dilutions was added to three replicate tubes of lauryl sulphate tryptose broth (LST) supplied with inverted durham's tubes. The inoculated LST tubes were incubated at $35 \pm 0.5^{\circ} \mathrm{C}$ for $48 \pm 2$ hours and examined after $24 \pm 2$ hours.

\subsection{Yeast and Mold count: - (APHA, 1985)}

One $\mathrm{ml}$ from each of the prepared dilutions was mixed by pouring technique in duplicate plates with $10-15 \mathrm{ml}$ of Sabouraud Dextrose agar containing 50 mg chloramphenicol per liter tempered at $45^{\circ} \mathrm{C}$. After solidification the inoculated plates were incubated at $25^{\circ} \mathrm{C}$ for 5 days. 
3.4. Enumeration of psychrotrophic bacteria using a standard plate count method: - (APHA, 1985)

One $\mathrm{ml}$ from previously prepared dilution was placed in duplicated plates using PCA. The inoculated plates were incubated at $7^{\circ} \mathrm{C}$ for 10 days.

\subsection{Lipolytic count: (APHA, 1992)}

One $\mathrm{ml}$ from each of the prepared dilutions was mixed by pouring technique in duplicate plates with $10-15 \mathrm{ml}$ of standard plate count agar supplied with tributyrin followed by incubation at $32^{\circ} \mathrm{C}$ for 2 days.

\subsection{Proteolytic count: (APHA, 1992)}

One $\mathrm{ml}$ from each of the prepared dilutions was mixed by pouring technique in duplicate plates with $10-15 \mathrm{ml}$ of standard plate count agar fortifiedwith $10 \%$ sterile skim milk and incubated at $32^{\circ} \mathrm{C}$ for 2 days.

\section{4- Statistical analysis:}

SPSS pocket program for windows (version 16, 2007) was used for the statistical analysis. Values of different parameters were expressed as the mean \pm standard error (SE).

\section{RESULTS}

Table 1: Statistical analytical results of microbial load in the examined Kareish cheese samples / $\mathrm{g}(\mathrm{n}=30)$.

\begin{tabular}{cccccc}
\hline & \multicolumn{2}{c}{ No. of positive samples } & \multirow{2}{*}{ Min } & Max & Mean \pm SE \\
\cline { 2 - 3 } & No. & $\%$ & & & \\
\hline Total bacterial count & 30 & 100 & $4.00 \times 10^{4}$ & $1.68 \times 10^{8}$ & $1.07 \times 10^{7} \pm 5.64 \times 10^{6}$ \\
\hline Total coliforms count & 30 & 100 & $2.30 \times 10^{2}$ & $4.30 \times 10^{6}$ & $2.55 \times 10^{5} \pm 1.59 \times 10^{5}$ \\
\hline Yeast and mold count & 30 & 100 & $3.00 \times 10^{3}$ & $2.80 \times 10^{6}$ & $1.83 \times 10^{5} \pm 9.25 \times 10^{4}$ \\
\hline Psychrotrophic count & 30 & 100 & $1.37 \times 10^{4}$ & $2.98 \times 10^{8}$ & $2.89 \times 10^{7} \pm 1.36 \times 10^{7}$ \\
\hline Lipolytic count & 30 & 100 & $4.20 \times 10^{3}$ & $1.52 \times 10^{7}$ & $1.23 \times 10^{6} \pm 5.18 \times 10^{5}$ \\
\hline Proteolytic count & 30 & 100 & $4.00 \times 10^{3}$ & $1.44 \times 10^{7}$ & $1.16 \times 10^{6} \pm 4.88 \times 10^{5}$ \\
\hline
\end{tabular}

Table 2: Statistical analytical results of microbial load in the examined Tallaga cheese samples / $\mathrm{g}(\mathrm{n}=30)$.

\begin{tabular}{cccccc}
\hline & \multicolumn{2}{c}{ No. of positive samples } & \multirow{2}{*}{ Min } & \multirow{2}{*}{ Max } & \multirow{2}{*}{ Mean \pm SE } \\
\cline { 2 - 4 } & No. & $\%$ & & & \\
\hline Total coliforms count & 13 & 43.33 & $<3$ & $9.30 \times 10^{3}$ & $9.58 \times 10^{2} \pm 4.32 \times 10^{2}$ \\
\hline Yeast and mold count & 29 & 96.67 & $<10$ & $9.00 \times 10^{3}$ & $6.10 \times 10^{2} \pm 3.34 \times 10^{2}$ \\
\hline Psychrotrophic count & 30 & 100 & $3.00 \times 10^{3}$ & $1.96 \times 10^{7}$ & $1.16 \times 10^{6} \pm 7.00 \times 10^{5}$ \\
\hline Lipolytic count & 30 & 100 & $4.40 \times 10^{3}$ & $1.71 \times 10^{7}$ & $9.32 \times 10^{5} \pm 5.63 \times 10^{5}$ \\
\hline Proteolytic count & 30 & 100 & $5.20 \times 10^{3}$ & $1.83 \times 10^{7}$ & $9.94 \times 10^{5} \pm 6.03 \times 10^{5}$ \\
\hline
\end{tabular}

Table 3: Statistical analytical results of microbial load in the examined Ras cheese samples / $g(n=30)$.

\begin{tabular}{|c|c|c|c|c|c|}
\hline & \multicolumn{2}{|c|}{$\begin{array}{l}\text { No. of positive } \\
\text { samples }\end{array}$} & \multirow{2}{*}{ Min } & \multirow{2}{*}{$\operatorname{Max}$} & \multirow{2}{*}{ Mean \pm SE } \\
\hline & No. & $\%$ & & & \\
\hline Total coliforms count & 24 & 80 & $<3$ & $4.30 \times 10^{2}$ & $88.1 \pm 21.11$ \\
\hline Yeast and mold count & 19 & 63.33 & $<10$ & $6.10 \times 10^{2}$ & $54.67 \pm 22.04$ \\
\hline Psychrotrophic count & 30 & 100 & $8.00 \times 10^{4}$ & $9.60 \times 10^{6}$ & $2.46 \times 10^{6} \pm 4.50 \times 10^{5}$ \\
\hline Lipolytic count & 30 & 100 & $2.02 \times 10^{5}$ & $9.60 \times 10^{6}$ & $2.91 \times 10^{6} \pm 4.13 \times 10^{5}$ \\
\hline Proteolytic count & 30 & 100 & $1.03 \times 10^{6}$ & $1.36 \times 10^{7}$ & $5.85 \times 10^{6} \pm 7.58 \times 10^{5}$ \\
\hline
\end{tabular}


Table 4: Statistical analytical results of microbial load in the examined small scale yoghurt samples / $g(n=30)$.

\begin{tabular}{|c|c|c|c|c|c|}
\hline & \multicolumn{2}{|c|}{$\begin{array}{c}\text { No. of positive } \\
\text { samples }\end{array}$} & \multirow{2}{*}{ Min } & \multirow{2}{*}{$\operatorname{Max}$} & \multirow{2}{*}{ Mean \pm SE } \\
\hline & No. & $\%$ & & & \\
\hline Total coliforms count & 16 & 53.33 & $<3$ & $2.10 \times 10^{3}$ & $1.94 \times 10^{2} \pm 79.47$ \\
\hline Yeast and mold count & 27 & 90 & $<10$ & $1.78 \times 10^{6}$ & $2.66 \times 10^{5} \pm 8.07 \times 10^{4}$ \\
\hline Psychrotrophic count & 28 & 93.33 & $<10$ & $9.90 \times 10^{6}$ & $7.81 \times 10^{5} \pm 3.37 \times 10^{5}$ \\
\hline Lipolytic count & 28 & 93.33 & $<10$ & $1.97 \times 10^{6}$ & $2.32 \times 10^{5} \pm 8.68 \times 10^{4}$ \\
\hline Proteolytic count & 28 & 93.33 & $<10$ & $6.20 \times 10^{6}$ & $3.32 \times 10^{5} \pm 2.12 \times 10^{5}$ \\
\hline
\end{tabular}

Table 5: Statistical analytical results of microbial load in the examined small scale cream samples / $g(n=30)$.

\begin{tabular}{cccccc}
\hline & \multicolumn{2}{c}{ No. of positive } & & & \\
& samples & Min & Max & Mean \pm SE \\
\cline { 2 - 3 } & No. & $\%$ & & & \\
\hline Total bacterial count & 30 & 100 & $3.10 \times 10^{4}$ & $2.66 \times 10^{7}$ & $3.35 \times 10^{6} \pm 1.23 \times 10^{6}$ \\
\hline Total coliforms count & 30 & 100 & $9.30 \times 10$ & $1.50 \times 10^{5}$ & $1.58 \times 10^{4} \pm 5.85 \times 10^{3}$ \\
\hline Yeast and mold count & 30 & 100 & 10.00 & $6.30 \times 10^{5}$ & $2.57 \times 10^{4} \pm 2.10 \times \times 10^{4}$ \\
\hline Psychrotrophic count & 30 & 100 & $4.40 \times 10^{4}$ & $1.66 \times 10^{7}$ & $2.51 \times 10^{6} \pm 6.95 \times 10^{5}$ \\
\hline Lipolytic count & 30 & 100 & $3.60 \times 10^{4}$ & $1.22 \times 10^{7}$ & $3.00 \times 10^{6} \pm 7.34 \times 10^{5}$ \\
\hline Proteolytic count & 30 & 100 & $7.10 \times 10^{4}$ & $2.73 \times 10^{7}$ & $5.21 \times 10^{6} \pm 1.27 \times 10^{6}$ \\
\hline
\end{tabular}

Table 6: Acceptable and unacceptable samples of the examined dairy products for total coliforms count according to the Egyptian standards (2005).

\begin{tabular}{|c|c|c|c|c|c|}
\hline \multirow{2}{*}{ Product } & \multirow{2}{*}{$\begin{array}{l}\text { Permissible limit of } \\
\text { total coliforms }\end{array}$} & \multicolumn{2}{|c|}{ Acceptable samples } & \multicolumn{2}{|c|}{ Unacceptable samples } \\
\hline & & No. & $\%$ & No. & $\%$ \\
\hline Kareish cheese & \multirow{7}{*}{$\begin{array}{l}\text { Not more than } 10 \\
c f u / g\end{array}$} & 0 & 0 & 30 & 100 \\
\hline Tallaga cheese & & 18 & 60 & 12 & 40 \\
\hline Ras cheese & & 6 & 20 & 24 & 80 \\
\hline Small scale yoghurt & & 14 & 46.67 & 16 & 53.33 \\
\hline Large scale yoghurt & & 30 & 100 & 0 & 0 \\
\hline Small scale cream & & 0 & 0 & 30 & 100 \\
\hline Large scale cream & & 30 & 100 & 0 & 0 \\
\hline
\end{tabular}

Table 7: Acceptable and unacceptable samples of the examined dairy products for total yeast and mold count according to the Egyptian standards (2005).

\begin{tabular}{|c|c|c|c|c|c|}
\hline \multirow{2}{*}{ Product } & \multirow{2}{*}{$\begin{array}{l}\text { Permissible limit of } \\
\text { total yeast and mold }\end{array}$} & \multicolumn{2}{|c|}{ Acceptable samples } & \multicolumn{2}{|c|}{ Unacceptable samples } \\
\hline & & No. & $\%$ & No. & $\%$ \\
\hline Kareish cheese & \multirow{2}{*}{$\begin{array}{c}\text { Not more than } 410 \\
c f u / g\end{array}$} & 0 & 0 & 30 & 100 \\
\hline Tallaga cheese & & 26 & 86.67 & 4 & 13.33 \\
\hline Ras cheese & $\begin{array}{l}\text { Not more than } 110 \\
\text { cfu/g }\end{array}$ & 25 & 83.33 & 5 & 16.67 \\
\hline Small scale yoghurt & \multirow{2}{*}{$\begin{array}{l}\text { Not more than } 10 \\
c f u / g\end{array}$} & 3 & 10 & 27 & 90 \\
\hline Large scale yoghurt & & 30 & 100 & 0 & 0 \\
\hline Small scale cream & \multirow{2}{*}{$\begin{array}{c}\text { Not more than } 20 \\
\text { cfu/g }\end{array}$} & 1 & 3.33 & 29 & 96.67 \\
\hline Large scale cream & & 30 & 100 & 0 & 0 \\
\hline
\end{tabular}




\section{DISCUSSION}

Many foods spoil due to microbial degradation with their metabolites being the cause of the off-flavours or the textural changes resulting in sensory rejection.

The results given in Table (1) showed that the mean values of microbial load of the examined Kareish cheese samples were $1.07 \times 10^{7} \pm 5.6^{4} \times 10^{6}, 2.55 \times 10^{5}$ $\pm 1.59 \times 10^{5}, 1.83 \times 10^{5} \pm 9.25 \times 10^{4}, 2.88 \times 10^{7} \pm$ $1.36 \times 10^{7}, 1.23 \times 10^{6} \pm 5.18 \times 10^{5}, 1.16 \times 10^{6} \pm 4.88 \times 10^{5}$ cfu / g for TBC, total coliforms count, total yeast and mold count, total psychrotrophic count, lipolytic count and proteolytic count, respectively.

Regarding the TBC, nearly similar results were recorded by Khair-Allah (2000), while higher results were postulated by El- Bessary (2006) and lower results were recorded by Ahmed (2012). For total coliforms count, nearly similar results were indicated by Shahin (2015), and higher results were recorded by El-Barbary (1999), but lower results were estimated by Abd El-Fattah (2013). For total yeast and mold count, our results were in agreement with Nawar (2001), higher results were postulated by Sharkawy (2018) but lower results were detected by El-Bagoury et al. (2014). For total psychrotrophic count, the obtained results were in agreement with Meshref and Hassan (2009), and some extent lower results were reported by Khair Allah (2000). For total lipolytic and proteolytic counts, lower results were showed by El-Bagoury et al. (2015).

Higher total bacterial count in Kareish cheese and cream samples gives an indication on general quality of the product through contaminated raw materials or unsatisfactory processing from sanitary point of view.

Presence of coliforms in dairy products in high counts such as in case of Kareish cheese may indicate unsanitary practices in cheese making process and may sometimes give rise to early blowing or gassing of the product. It is characterized by large gas holes, a spongy texture of cheese and generally occurs $1-2$ days after manufacture (Bintsis, 2006). Contamination of cheese with coliforms gives indication of bad hygienic conditions during production, handling and distribution and the possible presence of enteric pathogens (ICMSF, 1996).

In Table (2), the results showed that the mean value ofmicrobial load in the examined Tallaga cheese samples were $9.58 \times 10^{2} \pm 4.32 \times 10^{2}, 6.10 \times 10^{2} \pm$ $3.34 \times 10^{2}, 1.16 \times 10^{6} \pm 7.00 \times 10^{5}, 9.32 \times 10^{5} \pm 5.63 \times 10^{5}$ and $9.94 \times 10^{5} \pm 6.03 \times 10^{5} \mathrm{cfu} / \mathrm{g}$. For total coliforms count, total yeast and mold count, total psychrotrophic count, lipolytic count and proteolytic count respectively.
For total coliforms count, nearly similar results were detected by Ahmed (2012); the mean value of coliform count was higher than that reviewed by Hassan (2008b). For total yeast and mold count, nearly similar results were reported by Abdel- Elall et al. (2006), higher results were detected by Ahmed (2012). For total psychrotrophic count, results of Meshref and Hassan (2009) were in agreement with the obtained results. For the total lipolytic and proteolytic counts, higher results were noted by Sallam et al. (1991) and Awad et al. (2005), respectively.

The results given in Table (3) showed that the mean values of microbial load of the examined Ras cheese samples were $88.10 \pm 21.11,54.67 \pm 22.04,2.46 \times 10^{6}$ $\pm 4.50 \times 10^{5}, 2.91 \times 10^{6} \pm 4.13 \times 10^{5}$ and $5.85 \times 10^{6} \pm$ $7.58 \times 10^{5} \mathrm{cfu} / \mathrm{g}$ for total coliforms count, total yeast and mold count, total psychrotrophic count, lipolytic count and proteolytic count, respectively.

Comparing to the other results for total coliforms count, similar results were detected by Hassan (2008a), on the other hand, the mean value of coliform count was higher than those reported by both Salem (2017) and Bakr (2018). For total yeast and mold count, similar results were detected by Sharkawy (2018), higher results were indicated by ElBagoury et al. (2014), Shahin (2015). For total lipolytic and proteolytic counts, lower results were recorded by El-Bagoury et al. (2015).

Lower counts of coliforms and total yeast and mold in Ras cheese than the other products may be due to the heat treatment of milk during manufacturing and also refrigeration that decrease the counts of these organisms.

The inspection of the results in Table (4) revealed that the mean values of the microbial load of the examined small scale yoghurt samples were $1.94 \times 10^{2}$ $\pm 79.47,2.66 \times 10^{5} \pm 8.07 \times 10^{4}, 7.81 \times 10^{5} \pm 3.37 \times 10^{5}$, $2.32 \times 10^{5} \pm 8.68 \times 10^{4}$ and $3.32 \times 10^{5} \pm 2.12 \times 10^{5} \mathrm{cfu} / \mathrm{g}$ for total coliforms count, total yeast and mold count, total psychrotrophic count, lipolytic count and proteolytic count, respectively.

For total coliforms count, the results were in line with that showed by Abou El-Makarem (2013), while Morsy (2016) found higher mean value than the noted results but lower results were declared by El-Bakri et al. (2009). For total yeast and mold count, similar results were recorded by Osman (2015), higher results were reported by Zeinhom (2007) and lower results were detected by Abou El- Makarem (2013). For total psychrotrophic count, lower results were detected by El- Malt et al. (2013).

Yeasts and molds counts are used as an index of the proper sanitation quality. Defects such as rancidity, 
softness and colour defects arise mainly from contamination by yeasts and molds. Moreover, in view of the potential ability of some molds to produce mycotoxins during their growth, thus their presence possess potential hazards to food safety and human health (Kivance, 1990).

The results given in Table (5) showed that the microbial load in the examined all small scale cream samples were with mean values of $3.35 \times 10^{6} \pm$ $1.23 \times 10^{6}, 1.58 \times 10^{4} \pm 5.85 \times 10^{3}, 2.57 \times 10^{4} \pm 2.10 \times 10^{4}$, $2.51 \times 10^{6} \pm 6.95 \times 10^{5}, 3.00 \times 10^{6} \pm 7.34 \times 10^{5}$ and $5.21 \times 10^{6} \pm 1.27 \times 10^{6} \mathrm{cfu} / \mathrm{g}$ for TBC, total coliforms count, total yeast and mold count, total psychrotrophic count, lipolytic count and proteolytic count, respectively.

Comparing to the other results for TBC, similar results were detected by Meshref (2013) while ElGendi et al. (2013) showed an average count lower than our results. For total coliforms count, similar results were detected by El-Gendi et al. (2013), higher results were reported by El-Barbary (1999) and Meshref (2013). For total yeast and mold count, lower results were detected by El- Gendi et al. (2013). For total psychrotrophic and proteolytic counts, nearly similar results were detected by ElSamragy et al. (1992).

Psychrotrophs have been a major problem to the dairy industry for many years and will continue to be a problem in the future. Some of these psychrotrophs have the ability to form hydrolytic thermostable enzymes causing spoilage to some milk and dairy products constituents as fat and protein stored in the refrigerator (Dogan and Boor, 2003). These enzymes retain from 30 to $100 \%$ of their activity after conventional heat treatment of milk (pasteurization: $72{ }^{\circ} \mathrm{C}$ for $15 \mathrm{sec}$; ; sterilization $138{ }^{\circ} \mathrm{C}$ for $2 \mathrm{sec}$.; 149 for10 sec.). Up to $30 \%$ losses of modern dairy industry are due to spoilage and reduced product quality caused by psychrotrophic microorganisms (Randolph, 2006).

The counts of lipolytic and proteolytic bacteria are increasing in relation to the rate of initial raw milk contamination and time of cold storage of milk, the content of free fatty acids (FFA) is also rising and raw milk pH is decreasing (Celestino et al., 1996).

Proteolytic microorganisms produced important physico-chemical changes of the protein content through reducing -and in some cases, even slightly higher - until the end of shelf-life, caused by the decomposition of proteins due to proteolysis processes and the proteins environmental releases of microorganisms development (Rotar et al., 2009).

In examination of yoghurt and cream produced in large dairy plants, it showed that these products are free from coliforms, yeast and mold, psychrotrophic as well as lipolytic and proteolytic microorganisms and this is due to heating of milk at high temperature and following of strict hygienic measures during processing, handling, packaging and storage of such products.

The inspection of the results in Table (6) revealed that $0(0 \%), 18(60 \%), 6(20 \%), 14(46.67 \%), 30(100 \%)$, $0(0 \%)$ and $30(100 \%)$ of the examined Kareish, Tallaga, Ras cheeses, small and large scale yoghurt, small and large scale cream samples respectively have acceptable quality for the total coliforms count $c f u / g$ according to the Egyptian standards (2005).

The results in Table (7) showed that $0(0 \%)$, $26(86.67 \%), \quad 25(83.33 \%), \quad 3(10 \%), \quad 30(100 \%)$, $1(3.33 \%)$ and $30(100 \%)$ of the examined Kareish, Tallaga, Ras cheeses, small and large scale yoghurt, small and large scale cream samples respectively have acceptable quality for the total yeast and mold count $c f u / g$ according to the Egyptian standards (2005).

\section{CONCLUSION}

Results of the study clearly indicated that the bacteriological quality of the examined dairy products was inferior. Most of the examined samples especially those obtained from small scale are highly contaminated with large number of total bacterial count, coliforms, psychrotrophs, yeast and molds, lipolytic and proteolytic microorganisms. The presence of these organisms and in high number render the processed dairy products unfit for human consumption and of inferior quality through the development of undesirable changes which reflecting unhygienic measures, inadequate heat treatment during the manufacture, using bad quality ingredients or additives and improper sanitation during storage, handling and distribution. Yeasts and molds may cause undesirable changes in the contaminated food and may expose the consumer to public health hazards.

\section{REFERENCE}

Abdel-Elall, A.A.; Saudi, A.M.; Moawad, A.A. and Ismail, M.M.A. (2006): Microbiological and compositional status of Egyptian white soft cheese. J. Egypt. Vet. Med. Assoc, 66(3): 25-35.

Abd El-Fattah, S.A.S. (2013): Microbial profile of some dairy products. Ph.D. Thesis, Fac. Vet. Med., Alexandria Univ. Egypt.

Abou El-Makarem, H.S.M. (2013): Biocontrol of some foodborne pathogens isolated from traditional fermented milk. Ph.D. Thesis, Fac. Vet. Med., Alexandria Univ. Egypt. 
Ahmed, E.G.H. (2012): Microbiological evaluation of soft cheeses sold in Beni-Suef markets. Ph.D. Thesis, Fac. Vet. Med., Beni-Suef Univ., Egypt.

APHA (1985): Standard Methods for the Examination of Dairy Products. $15^{\text {th }}$ ed., American Public Health Association, G.H. Richardson, Washington D.C.

APHA (1992): Standard Methods for the Examination of Dairy Products. $16^{\text {th }}$ ed., American Public Health Association, Washington DC., USA.

Awad, E.I.; Abd-El Aal, S.F.A. and Ibrahim, M.A. (2005): Occurrence of proteolytic bacteria in milk and some dairy products. Zag. Vet. J., 33(3): 183-189.

Bakr, A.M. (2018): Indicator organisms as indices of quality for milk and some dairy products. M.V. Sci. Thesis, Fac. Vet. Med., Beni-Suef Univ., Egypt.

Bintsis, T. (2006): Quality of brine. In: Brined cheese, Edited by Tamime, A. pp: 264-301, Blackwell Publishing.

Celestino, E.L.; Iyer, M. and Roginski, H. (1996): The effects of refrigerated storage on the quality of raw milk. Australian J. Dairy Technol., 51: 59-63.

Chen, L.; Daniel, R.M. and Cool bear, T. (2003): Detection and impact of protease and lipase activities in milk and milk powder (review). Int. Dairy J., 13: 255-275.

Davidson, P.M.; Roth, L.A. and Gambrel-Lenarz, S.A. (2004): "Coliform and other indicator bacteria," In: Standard Methods for the Examination of Dairy Products. $17^{\text {th }} \mathrm{ed}$, Wehr H.M., Frank J.F., (Editors Washington, DC: American Public Health Association), 187-227.

Death, H.C. and Fitz-Gerald (1983): Lipolytic enzymes and hydrolytic rancidity in milk products. Dairy Chemistry 2: Lipid Ed. Fox., P.F. 195-239.

Dogan, B. and Boor, K.J. (2003): Genetic diversity and spoilage potentials among Pseudomonas spp. isolated from fluid milk products and dairy processing plants. Appl. Environ. Microb. J.,69: 130-138.

Egyptian standards (2005): Egyptian organization for standardization and quality.

a- ES1008-4 (2005): Soft cheese, part 4: Kareish cheese.

b- ES1008-5 (2005): Soft cheese, part 5: cold stored cheese.

c- ES1007-4 (2005): Hard cheese, part 4: Romi (Romy) cheese.

d- ES1000 (2005): Plain yoghurt.

$\boldsymbol{e}$ - ES154-2 (2005): Milk and dairy products, part 2: Natural liquid cream.

El-Bagoury, A.M. and Mosaad, A.A. (2002): Incidence of Salmonella and Escherchia coli in Kareish cheese with special reference to heat stable enterotoxin producing Escherichia coli using polymerase chain reaction. Minufyia Vet. J., 2(1): 59-66.

El-Bagoury, A.M.; Hammad, A.M. and Dawood, S.A. (2014): Prevalence of fungi in locally produced cheese and molecular characterization of isolated toxigenic molds. Banha. Vet. Med., J., 27: 9-20.

El-Bagoury, A.M.; Heba, A. Hussein and Hoda, A. Mahrous (2015): Lipolytic and proteolytic activities of psychrotrophic microorganisms isolated from raw milk and cheeses in Egypt. Conf. Food Safety. J., (1): 76-78.

El-Bakri, J.M.; Ibtisam, I. and El-zubeir, E.M. (2009): Chemical and microbiological evaluation of plain and fruit yoghurt in Khartum State, Sudan. Int. J. Dairy Sci., 4(1): $1-7$.

El-Barbary, M.M.A. (1999): Occurrence of enteric microorganisms in some dairy products in Sharkia governorate. M. V. Sci. Thesis, Fac. Vet. Med., Zagazig Univ. Egypt.

El-Bessary, M.M. (2006): Sanitary status of milk and some milk products marketed in suburbs of Assuit Governorate. Ph.D. Thesis, Fac. Vet. Med. Assuit Univ., Egypt.

El- Gendi, M.N.; Marwa and El- Shreef Lamiaa, M.T.A. (2013): Microbiological investigation of some dried mixes of dairy desserts sold in Assuit city. Assuit Vet. Med. J., 59: 137.

El-Malt, Laila M.; Abdel Hameed Karima, G. and Mohammed, A.S. (2013): Microbiological evaluation of yoghurt products in Qena city, Egypt. Vet World, 6(7): 400-404.

El- Samragy, Y.A.; El- Nockrashy, S.A.; Effat, B.A. and Magdoub, M.N.I. (1992): Proteolytic psychrotrophic bacteria in some dairy products in Egypt. Die Nahrung 36(2): 181-189.

(FAO) Food and Agriculture Organization (1992): Manual of food quality control. 4. Rev.1. Microbiological analysis. Washington, D.C. Food Prot., $58: 132-138$.

Grieve, P.A. and Kitchen, B.J. (1985): Proteolysis in milk: the significance of proteinases originating from milk leucocytes and a comparison of the action of leucocyte bacterial and natural milk proteinases on casein. $\mathrm{J}$. Dairy Res., 52: 101-112.

Hassan, M.A.A. (2008a): Assessment of probable microbiological hazards in some dairy products. M.V. Sci., Thesis, Fac. Agri., Ain shams Univ., Egypt.

Hassan, W.S.A. (2008b): Microbiological evaluation of some white soft cheeses locally manufactured and sold in Assuit city. M.V. Sci., Thesis, Fac. Vet. Med., Assiut Univ., Egypt.

ICMSF (1996): "International Committee of Microbiological Specification of Food, Microorganism in foods. Microbiological specification of food pathogens, $1^{\text {st }}$ ed. Black 
academic and professional, London, pp.: 112300.

Khair - Allah, H.M.A. (2000): Safety and quality of some dairy products through microbial criteria. M.V. Sci. Thesis, Fac. Vet. Med., Alexandria Univ., Egypt.

Kivance, M. (1990): Mould growth and presence of aflatoxin in some Turkish cheese. J. Food Safety, 10: 289-294.

Ledenbach, L.H. and Marshall, R.T. (2009): Microbiological spoilage of dairy products. Springer Science+Business Media pp.: 1-28.

Meshref, A.M.S. (2013): Bacteriological quality and safety of raw cow's milk and fresh cream. Slov. Vet. Res, 50 (1): 21-30.

Meshref, A.M.S. and Hassan, G.M. (2009): Bacteriological status of some soft cheeses sold in Beni-Suef city. Assiut Vet. Med. J.,55(122): 112-123.

Minervini, F.; Montagna, M.T.; Spilotros, G.; Monaci, L.; Santacroce, M.P. and Visconti, A. (2001): Survey on microflora of cow and buffalo dairy products from Southen Italy. Int. J. Food Microbiol.,69: 141. Dairy Sci. Abst., 64: 181. (2002)

Morsy, B.A.M. (2016): Quality assessment and safety system of milk and some milk products in university hostels. M.V. Sci., Thesis, Fac. Vet. Med., Beni-Suef Univ., Egypt.

Mossel, D.A.A. (1983): Essential and preservatives of the microbial ecology of foods. In: Roberts, T.A., Skinner, F.A., Editors. Food Microbiology: advances and prospects. London: Academic Press.

Moyer, C.L. and Morita, R.Y. (2007): Psychrophiles and psychrotrophs. In: Morita RY, Editor. Encyclopedia of Life Sci. John Wiley \& Sons Ltd; Chichester, pp.: 1-6.

Nawar, D.M.M. (2001): Hygienic quality of some street- venderd dairy products. M.V. Sci. Thesis, Fac. Vet. Med., Alexandria Univ., Egypt.

Osman, O.M.M. (2015): Quality evaluation of some fermented milk sold at local market. Ph.D. Thesis, Fac. Vet. Med., Alexandria Univ., Egypt.

Özdemir, S.; Yangilar, F. and Ozdemir, C. (2010): Determination of microbiological characteristics of Turkish Karinkaymagi cheeses packaged in different materials. Afr. J. Microbiol. Res., 4 (9): 716-721.

Pal, M. and Awel, H. (2014): Public health significance of Listeria monocytogenes in milk and milk products. J. Vet. Pub. Health, 12: $1-5$.

Ralyea, R.D.; Wiedmann, M. and Boor, K.J. (1998): Practical tracking in a dairy production system using phenotypic and ribotypic methods. J. Food Prot., 61: 1336-1340.

Randolph, H. (2006): Identifying spoilage bacteria and potential shelf- life problems. Dairy Food,1-3.

Rohm, H.; Eliskasses-Lechner, F. and Bräuer, M. (1992): Diversity of yeasts in selected dairy products. J. Appl. Bacteriol., 72: 370-376.

Rotar, M.A.; Semeniuc, C.; Apostu, S.; Gus, C.; Vodnar, D. and Ticrea, L. (2009): Influence of proteolytic microorganisms on dairy products quality. Bulletin UASVM Agriculture, 66 (2): 432- 436.

Salem, H.A.M. (2017): Quality criteria for some dairy products. M.V. Sci. Thesis, Fac. Vet. Med., Beni-Suef Univ., Egypt.

Sallam, S.S.; Hafez, N.M.; El-Shinawy, S.H. and ElKholy, A.M. (1991): Lipolytic organisms in an Egyptian cheese. Beni-Suef, Vet. Med. Res., 1(2): 399-407.

Samaržija, D.; Podoreški, M.; Sikora, S.; Skelin, A. and Pogačić, T. (2007): Spoilage microorganisms in milk and dairy products. Mljekarstvo, 57: 4.

Shahin, H.F. (2015): Sanitary evaluation of curd dairy products. M.V. Sci., Thesis, Fac. Vet. Med., Alexandria Univ., Egypt.

Sharkawy, S.W.A. (2018): Mycological studies on milk and some dairy products. M.V. Sci. Thesis, Fac. Vet. Med., Beni-Suef Univ., Egypt.

Sofu, A. and Ekinci, F.Y. (2007): Estimation of storage time of yoghurt with artificial neural network modeling. J. Dairy Sci., 90: 31183125 .

Tamime, A.Y. and Robisons, R.K. (2007): Backround to manufacturing practice. In: Tamime and Robinson's Yogurt: Science and Technology, $3^{\text {rd }}$ edition; Woodhead Publishing LTD: Cambridge, UK; pp: 11-118.

Weerathilake, W.A.D.V.; Rasika, D.M.D.; Ruwanmali, J.K.U. and Munasinghe, M.A.D.D. (2014): The evolution, processing, varieties and health benefits of yoghurt. Int. J. Sci. Res. Pub., 4(4): 1-10.

Wilbey, R.A. (2005): Microbiology of cream and butter. Dairy microbiology handbook: The Microbiology of Milk and Milk Products, UK. pp: 123-174.

Wolfe, B.E.; Button, J.E.; Santarelli, M. and Dutton, R.J. (2014): Cheese rind communities provide tractable systems for in situ and in vitro studies of microbial diversity. Cell 158: 422-433.

Zeinhom, M.M.A. (2007): Quality assurance of yoghurt during processing. M. V. Sci. Thesis, Fac. Vet. Med., Beni-Suef, Cairo Univ., Egypt. 


\section{تأثير الميكروبات المفسدة علي بعض المنتجات اللبنية}

جمال محمد حسن ، عرفة مشرف سليمان ، محمد معروف علي زينهم ، محد صفوث عبد الحليم

E-mail: msafwat1992@yahoo.com Assiut University web-site: www.aun.edu.eg

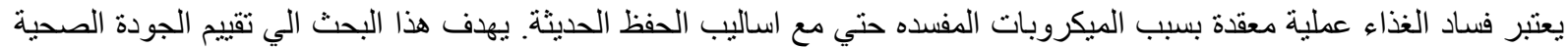

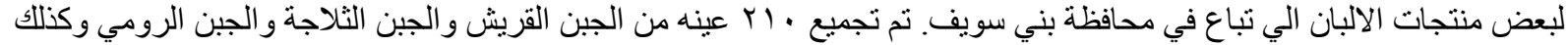

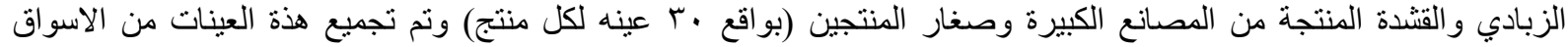

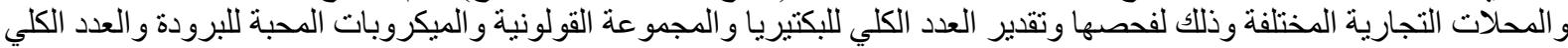

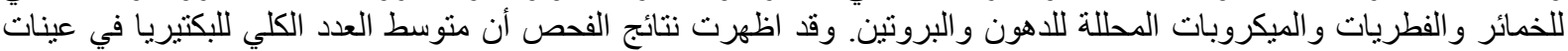

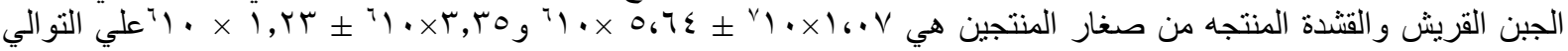

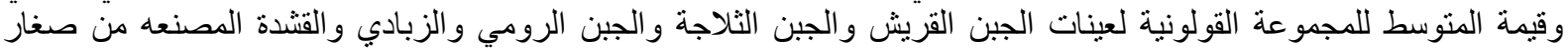
المنتجين هي المنوسط

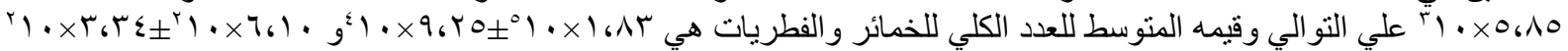
و البرودة هي

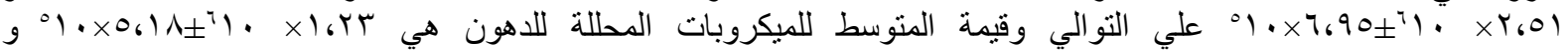
( )

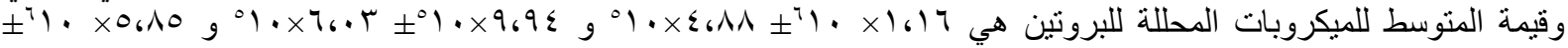

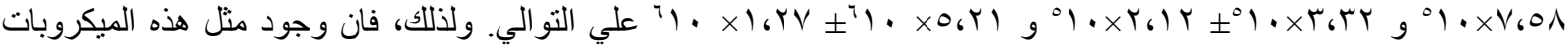

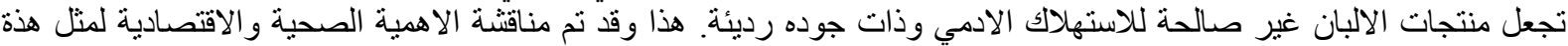
الميكروبات في بعض منتجات الالبان. 